\title{
Implementering av arbetslinjen inom sjukförsäkringen - konsekvenser för invandrarklienter
}

TOLA B. JONSSON

\section{Arbetslinjen som en central strategi vid rehabilitering av}

långtidssjuka skapar problem för vissa invandrarklienter.

Problemen beror påatt skillnader i synsätt mellan försäkringskassans handläggare och klienten leder till att konfliktfyllda situationer uppstår. En hypotes som artikeln

frambringar är att ju fler ,komplicerade invandrarärenden ' handläggaren handhar, desto mer problematiska upplevs invandrarärenden generellt.

Återgång till arbete är ett viktigt mål vid rehabilitering av långtidssjuka inom sjukförsäkringen. En rad förändringar inom sjukförsäkringen genomfördes i början av 1990talet. Dessa syftade till att underlätta återinträde på arbetsmarknaden och som en följd minska förtidspensioneringarna. De genomförda reformerna går under beteckningen nya arbetslinjen (Prop 1990/91:141). Arbetslinjen skapar problem för dem som inte passar in i de organisatoriska ramarna.

Tola B. Jonsson är doktorand i sociologi vid Uppsala universitet och forskningsassistent vid Högskolan i Örebro.
Detta upptäckte jag när jag genomförde en studie av sjukförsäkringssystemets möte med långtidssjukskrivna invandrare.

Jag hade väntat mig att mötet mellan försäkringskassans handläggare och klienterna skulle handla om sjukdom relaterad till arbetsförmåga, men det framkom tydligt att samtalen konsekvent styrdes bort från sjukdom och till frågor om arbete. Arbetslinjen är alltså inte bara något som stipuleras i policydokumenten, utan en central strategi i mötet med klienter. Den uttalades inte direkt, men framstod ändå som mycket påträngande i mötet. Jag började fundera över hur handläggarna gjorde för att förmedla ar-

Tola. B Jonsson - Implementeringen av arbetslinjen... 
betslinjen till klienterna. Vad i deras agerande fick den att framstå så tydligt?

En fråga som den här artikeln handlar om är hur handläggarna sargumenterarı för den nya arbetslinjen i mötet med långtidssjuka. Ytterligare en fråga som jag försöker belysa utifrån mitt speciella intresse för invandrare är om effekterna av argumenteringen blir olika för invandrare respektive svenskar.

Syftet med denna artikel är att identifiera och beskriva hur arbetslinjen implementeras i mötet mellan försäkringskassans rehabiliteringshandläggare och deras klienter. Särskild uppmärksamhet riktas på invandrarklienter. Dessutom vill jag till de fenomen som identifieras utifrån empirin koppla ett par begrepp som kan betraktas som bakomliggande mekanismer.

Jag börjar med att beskriva metod och min arbetsmodell. Därefter presenterar jag kort de teoretiska utgångspunkterna. När jag sedan redogör för det empiriska materialet redovisar jag först de argument، som handläggarna använder vid implementeringen av arbetslinjen. Sedan försöker jag klarlägga arbetslinjens effekter för invandrare genom att uppmärksamma kritiska händelser $^{1}$ i mötet. Avslutningsvis sammanfattar jag de slutsatser som framträder av analysen med samlad uppmärksamhet på invandrarklienter.

1 Miles och Huberman (1994) anför en ,kritisk händelser som "those events seen as critical, influential, or decisive in the course of some process." (s 115), dvs. händelser som utmärker sig i det empiriska materialet. IKritiska händelserı som jag särskilt fokuserat på är situationer då missförstånd eller meningsskiljaktigher av hur situationen ska tolkas uppstår på grund av klientens invandrarbakgrund.

\section{Metod}

Artikeln bygger på en studie vid ett försäkringskassekontor i ett storstadsområde. I det aktuella kassakontorets upptagningsområde utgör invandrarna 48 procent av befolkningen. Av kassans klienter hade ca 60 procent $^{2}$ invandrarbakgrund. Denna grupp var alltså överrepresenterad. Handläggarna uppgav också att de upplevde vissa invandrarärenden som särskilt komplicerade att arbeta med. Generellt sett såg de invandrarer som en problematisk grupp att arbeta med.

Studiens fokus ligger på mötet mellan handläggare och klient och de fenomen som uppstår i relationen dem emellan. Även relationen mellan fenomenen och den kontext som omger mötet är av centralt intresse. Jag gjorde observationer av möten mellan handläggarna och långtidssjukskrivna klienter. Sammantaget omfattar materialet 24 observationer (12 olika handläggare och 23 olika klienter varav 17 personer med invandrarbakgrund ${ }^{3}$ och 6 svenskar). Dessutom genomförde jag intervjuer med rehabiliteringshandläggarna efter observationsperioden. Samtidigt deltog jag i det dagliga arbetet på kontoret. Den öppna och positiva inställning som personalen hade till forskningsarbetet gav en god inblick i handläggarnas arbetssituation. Studien genomfördes under hösten 1994.

Vid analysarbetet har jag dels identifierat hur handläggarna förmedlar arbetslinjen i

2 Uppgifterna grundar sig på kassapersonalens uppgifter från 1993.

3 Invandrarbakgrund betyder här att handläggarna tillskriver klienterna etiketten invandrares. 


\begin{tabular}{|l|l|}
\hline \multicolumn{2}{|l|}{ Figur l } \\
\hline Empiri & Bakomliggande mekanismer \\
\hline $\begin{array}{l}\text { Handläggarnas sargument< vid implementeringen } \\
\text { av arbetslinjen i mötet med klienten }\end{array}$ & Byråkratisk auktoritet \\
\hline «ritiska händelser i mötet med invandrarklienter & Arbetets värde \\
\hline
\end{tabular}

mötet. Dessa uttryck kallar jag rargument، Dels har jag särskilt noterat situationer då handläggarnas argument för arbetslinjen leder till störningar i relationen på grund av klientens invandrarbakgrund. Dessa situationer benämner jag kritiska händelserı. 'Argumenten ' har sedan konfronterats mot teoretiskt härledda antaganden om drivkrafter för arbete. Vidare illustreras kopplingen till två begrepp, vilka uppfattas som bakomliggande mekanismer, dvs. de ses som verkande i verkligheten men har analyserats genom abstraktionsprocesser (Sayer 1984, Karlsson m.fl. 1991). De två begreppen är byråkratisk auktoritet och arbetets värde. I slutdiskussionen knyts även de kritiska händelsernar till dessa begrepp.

Arbetsmodellen kan beskrivas i figur 1 ovan.

Även om det främst var handläggaren som stod i centrum för mitt intresse vid observationerna bestod mötet av två deltagande parter som båda påverkade interaktionen och hur den utvecklades. Jag har därför valt att även presentera klientens responser kring temat arbetslinjen. Det kan ge läsaren en uppfattning om komplexiteten i den process som uppstår vid varje konkret möte. Tolkningen av klienternas reaktioner kan ses som tentativa då de inte följs upp i denna studie.

\section{Teoretiska utgångspunkter}

För att implementera arbetslinjen försöker handläggarna på olika sätt motivera klienterna för arbete ${ }^{4}$. Dessa utgår från vissa antaganden om individuella motiv för arbete. Antagandena kan indelas i två huvudgrupper. Dels en grupp som utgår från en byråkratisk dimension och dels en grupp som tar sin utgångspunkt $i$ arbetets dimension.

Den byråkratiska dimensionen handlar om handläggarens möjlighet till byråkratisk maktutövning, dvs. att använda regelsystemet och handläggningsrutiner som argument i klientmötet. Handläggaren personifierar organisationen i mötet med klienten. Som sådan måste hon se till att klientens behov faller inom organisationens specialiseringsområde och att regelsystem och handläggningsrutiner följs. Båda dessa moment innefattar kontrollerande inslag (Prottas 1979, Lipsky 1980, Midré 1990, Johansson 1992). Från ett organisationsperspektiv har alltså handläggaren legitim makt att göra detta. Möjligheten att använda regler och

${ }_{4} \quad$ Forskningen kring arbete och arbetets värde har i stort koncentrerats på lönearbete/anställning och därmed satt likhetstecken arbete och lönearbete. Arbetslinjen inom sjukförsäkringen är också intimt sammankopplad med arbete som lönearbete/anställning.

Tola. B Jonsson - Implementeringen av arbetslinjen... 
rutiner för implementering av arbetslinjen förstärks bl.a. av förväntningar om ett konstruktivt samspel med klienten, den s.k. ssamspelsmodellen och myndighetskontaktens ofrivilliga karaktär.

Arbetets dimension kan hänföras till konsekvenser av och drivkrafter för arbete. Försörjning som en konsekvens av arbete är föga kontroversiell. Marie Jahoda (1981: 118) påpekar att arbete också har andra konsekvenser. Hon menar att man kan göra indelningen mellan å ena sidan arbetets avsedda primära konsekvenser, dvs. försörjning, och å andra sidan arbetets icke avsedda, sekundära konsekvenser. Exempel på sekundära konsekvenser är att arbete ger tidsstruktur åt dagen, innebär sociala kontakter utanför kärnfamiljen, definierar personens status och identitet samt framtvingar aktivitet i sig.

Mats Friberg $(1975,1976)$ har utvecklat en typologi över drivkrafter eller incitament för arbete. Den innehåller fyra typer av incitament, nämligen tvång, materiella incitament, normativa incitament och inherenta incitament.

\section{Drivkrafter för arbete och sjukförsäkringen}

Om jag applicerar Fribergs typologi över incitament på socialförsäkringens område finner jag att regelsystemet och handläggningsrutinerna kan verka som tvingande incitament, om än inte i den negativa form som Friberg anför. Detta har sin grund i handläggarens auktoritet som organisationsrepresentant.

Den nya arbetslinjen inom sjukförsäkringen bygger på specifika antaganden om arbetet och dess värde för individ och kollektiv. Friberg framhåller sociala argument, dvs. involvering och identifikation med ledare som ett viktigt incitament. En skillnad som framkommer är att de exempel som Friberg refererar främst rör politiska och ideologiska rörelser på makronivå, medan handläggarnas argument i mitt material kan sägas tillhöra den relationella nivån. Det betyder att identifikation här främst handlar om att tillhöra och identifiera sig med det arbetande kollektivet, underförstått att arbeta innebär att ha högre status än att inte arbeta.

När det gäller Fribergs s.k. internaliserade argument finner jag att valet av rubricering är illa vald. Även sociala och inherenta incitament kan vara internaliserade. Däremot ser jag Fribergs uppdelning mellan moraliska, dvs. innifrảnstyrda eller omedvetna, och ideologiska incitament, dvs. medvetna ställningstaganden, som intressant och relevant för det empiriska materialet. Slutligen, tar de inherenta drivkrafterna fasta på de inneboende egenskaperna hos arbetet, dvs. att arbetet är ett mål i sig. Det erbjuder aktivitet och är därigenom spänningsreducerande(Friberg 1975:59, 1976:36)

Genom att koppla ihop Jahodas konsekvenser med övriga drivkrafter i Fribergs typologi finner jag att de materiella drivkrafterna kan sammanföras med antaganden om lönearbetets primära konsekvens. Medan de sociala respektive moraliska och ideologiska drivkrafterna (internaliserade enligt Fribergs terminologi), liksom de inherenta, faller under Jahodas sekundära konsekvenser.

I det empiriska materialet försöker försäkringskassans handläggare att motivera 
de långtidssjukskrivna klienterna för arbetslinjen genom att hänvisa till dels de byråkratiska förutsättningarna och dels olika aspekter på arbete. Hur detta går till kommer jag att redogöra för i följande avsnitt.

\section{Implementering av arbetslinjen}

I mötet med klienterna manifesteras antaganden om drivkrafter för arbete genom att handläggarna explicit eller implicit argumenterar för arbetslinjen. De empiriska argument، som återfinns i data beskrivs nedan. Därefter konfronteras handläggarnas argument med de iteoretiskt härledda antagandena om incitament för arbete enligt ovan.

\section{Argument i mötet med klienten}

I mötet mellan handläggarna och klienten framkommer tydligt hur stark genomslagskraft arbetslinjen har. Genom handläggarnas agerande i ord och handling står det klart att syftet med rehabiliteringsverksamheten är återgång till arbete. Samtalet med klienten kommer därför mycket att handla om arbete och hur vägen fram till arbete ska se ut. Man kan säga att handläggarna anför argument för arbetslinjen. De argument som jag har identifierat kan indelas i följande kategorier: 1) Byråkratiska argument, 2) försörjningsargument, 3) sociala argument, 4) moraliska argument, 5) ideologiska argument och 6) inherenta argument. Jag menar inte att dessa kategorier är varandra uteslutande, men de representerar argument med en genensam innebörd eller kärna. Samma uttalande eller uttryck kan också implicera olika argument. Menings- sammanhanget fick bli avgörande för kategoriseringen av argumenten.

\section{1) Byråkratiska argument}

Regelsystemet innefattar övergripande principer och lagar som föreskriver klientens rättigheter och skyldigheter, medan handläggningsrutinerna fungerar som verktyg för handläggaren att utföra sina arbetsuppgifter på ett rationellt sätt.

I kontakten med klienterna refererar handläggarna ofta till rreglernar. Reglerna fungerar som ett samlingsnamn för principer, lagar och rutiner. I det konkreta mötet använder handläggarna två olika strategier för att hänvisa till rreglernar. Den första, informationsstrategin, innebär att klienten upplyses om rehabiliteringens syfte och arbetsgången. Det görs vid det första besöket och därefter i samband med att olika förslag till åtgärder presenteras. På så sätt framställs handläggningen som objektiv och rättvis. Klienten ges också möjlighet att ställa frågor. Handläggarna uppger att de finner ett pedagogiskt värde $i$ att ge information om systemet. De menar att det hjälper klienten att förstå vad rehabiliteringen syftar till och olika aktörers ansvar och skyldigheter. När klienten förstår hur systemet fungerar verkar det motiverande i sig. Dessutom bäddar den för att den förväntade ssamspelsmodellen s skall fungera.

Den andra strategin, övertygelsestrategin, innebär att man hänvisar till reglerna när klienten uppfattas vara icke samarbetsvillig. Det händer när handläggaren och klienten har olika uppfattningar om vilka åtgärder som skall vidtas, tolkar intyg olika, osv. Övertygelsestrategin visar sig i mötet genom att handläggaren förklarar att hon mås- 
te följa reglerna. Det kan uttryckas på olika sätt. Låt mig ge ett exempel: Under ett möte försöker handläggaren motivera klienten att delta i arbetsträning vid Samhall. Klienten menar att hon inte kommer att kunna arbetsträna på grund av sina fysiska besvär. Handläggaren påpekar att arbetsträning hör till rutinerna. Om klienten inte ställer upp på detta kan sjukpenningsersättningen hållas inne "enligt reglernau. Senare under mötet då klienten upprepat att hon tvivlar på att hon kommer att lyckas med arbetsträningen då hon knappt orkar göra något alls hemma påpekar handläggaren att hon tyvärr inte kan göra några undantag för de speciella skäl som klienten anför för att slippa arbetsträna. Hon säger: „Det är inte jag som bestämmer. Jag måste följa reglerna.»

I de fall då personerna har olika uppfattningar kan handläggarna använda regelsystemet genom att erbjuda belöningar eller utdela bestraffningar. Belöningar kan ges t.ex. genom att framhålla den högre ersättningsnivån vid rehabiliteringinsatser (rehabiliteringsersättning var under de observerade perioden högre än vanlig sjukpenning). Sanktioner kan vara hot om att sjukpenningen dras in om klienten inte ställer upp på de åtgärder som ingår $i$ handläggningsrutinerna. Istället för samspel präglas mötet av att byråkraten blir dominerande och dikterar villkoren.

Handläggningsrutinerna framträder mycket påtagligt i det enskilda mötet. Också av handläggarnas egna beskrivningar av ärendehandläggningen framkommer att de försöker följa handläggningsrutinerna. Utredning av arbetsförmåga och arbetsträning är standardlösningar för att testa arbetsförmåga och få igång klienten i arbete. Köp av tjänstı, vilket omfattar allehanda tjänster som antas kunna hjälpa klienten att återgå till lönarbete, är en annan lösning. De åtgärder som föreslås begränsas av det lokala utbudet av rehabiliteringsproducenter och naturligtvis också av de ekonomiska ramarna.

Vid olika kontrollpunkter, inbyggda i handläggningsrutinerna, finns det möjlighet att definiera ut klienten ur rehabiliteringsprocessen. Tre tydliga varianter finns. För det första kan det ske genom att klienten bedöms som arbetsför efter utredning av arbetsförmåga. För det andra kan klienten bedömas som inte rehabiliteringsbar på grund av varaktig sjukdom vilket kvalificerar till förtidspension. Den tredje varianten är de fall då klienten inte fogar sig efter regelsystemet eller handläggningsrutinerna och därför utestängs.

Sammanfattningsvis finner jag att handläggarna i samtliga observationer använder byråkratiska argument mer eller mindre explicit. Det gäller oavsett i vilket stadium av rehabiliteringsprocessen klienten befinner sig. Bundenheten till handläggningsrutinerna är särskilt påtaglig. Handläggaren följer handläggningsrutinerna med tydligt syfte att slussa klienten fram till arbete. Variationen sker inom ramen för handläggarnas upplevda handlingsfrihet. ${ }^{5}$ Regelsystemet används för att motivera klienten att följa handläggningsrutinerna. I de fall informationsstrategin ‘ används bygger arbetets framskridande på klientens samtycke och aktiva deltagande, dvs. man följer ssamspels-

5 I en annan artikel (Jonsson 1996) redogör jag för de handlingsstrategier som handläggarna använder sig av i mötet med klienter inom ramen. 
modellenı. ¿Övertygelsestrategin ‘ har en mer tvingande karaktär, dvs. byråkraten dikterar ensidigt villkoren och klienten lyder mer eller mindre motvilligt.

\section{2) Försörjningsargument}

Försörjningsargumentet är svårt att urskilja som ett utkristalliserat eget argument hos handläggarna. En anledning till detta kan vara att arbetslinjen som ledstjärna implicerar försörjning genom arbete. En annan anledning kan vara att ersättningen från sjukförsäkringen av handläggarna ses som ett likvärdigt alternativ till försörjning genom arbete. I de fall handläggarna mera direkt framför försörjningsargumentet finns ideologiska eller moraliska undertoner som indikerar att argumenten knyts till rättigheten eller skyldigheten att arbeta.

När försörjningsaspekten förs på tal under mötet är det klienten som nämner det. Bland observationerna finns flera exempel på att klienter betraktar försörjning genom arbete som det inormalar alternativet och sjukpenningen som det sonormalar att utnyttja $i$ en akut situation. Några klienter med invandrarbakgrund betonar särskilt tydligt att de inte har för avsikt att "leva på bidrag». En libanesisk man säger att hans viktigaste mål är att arbeta, försörja familjen och betala sina lån. Han är mycket bedrövad över att hans sjukdom lett till att han inte kan gå tillbaka till sitt vanliga arbete. Han berättar hur han mycket aktivt, ja nästan desperat, söker nytt passande arbete. Min tolkning är att hans ansträngningar bottnar i en stark ansvarskänsla för sin familjens ekonomi och en kamp för att bevara sin autonomi gentemot samhället.

För vissa klienter kan också den lägre ersättningsnivån vara viktig. En ensamstående kvinna med barn nämner att hon vill komma igång med arbete så snart som möjligt eftersom hon inte kan försörja sig och barnet på sjukpenningen.

\section{3) Sociala argument}

I de observerade mötena framför handläggarna ofta argument för återgång till arbete som är knutna till arbetets sociala värden. Av dessa argument framgår att arbetet antas ge andra belöningar än de rent materiella. Argumenten förespeglar de positiva konsekvenser som arbetet antas kunna ge i form av relationer till arbetskamrater och social status i samhället. Människans självidentitet och gemenskap med andra människor sätts i relation till arbete och arbetskamrater.

Två typer av relationsargument framförs. Det ena typen av argument ger uttryck för att klienten kommer att må mycket bättre eller bli piggare om han eller hon börjar arbeta och träffar andra. Sociala kontakter ses som ett livselixir med läkande effekt. Det andra innebär att klienten är en viktig person $i$ en arbetsgemenskap, dvs. att klienten kommer att bidra till trivseln på arbetsplatsen. De relationsanknutna argumenten vädjar alltså till både egoistiska och altruistiska sidor hos klienten.

Statusargumenten anknyter oftast till det allmänt prestigefyllda i att ha ett arbete. Konkret uttryckt innebär det att familjen, släkten, vännerna och samhället tillerkänner den arbetande status. Ett intryck från observationerna är att statusargumentet oftare används när klienten är man, medan relationsargument används när klienten är kvinna. 
Ibland lyfts negativa konsekvenser av att inte arbeta fram. Uttalanden som handläggarna gör implicerar bl.a. att "bara gå hemman leder till isolering eller att inte ha arbete leder till statusförlust och minskat självförtroende.

Klienterna tar också upp de sociala konsekvenserna av arbete. Av deras uttalanden kan man uttolka att arbeta för dem bl.a. betyder: Att vara till nytta för samhället, att ha kontakter med människor utanför familjen, att inte ligga andra till last genom att leva på bidrag från välfärdssystemet och att vara jämställd.

Likheten i de sociala argument som framförs av handläggare och klienter är slående. Det ger sken av att det finns en allmän uppfattning om att människors arbete är förknippat med sociala relationer och social status, men också med att ha en funktion i samhället. Granskas enskilda möten förekommer dock märkbara skillnader i tolkningar av arbetets sociala vinster mellan handläggare och klient. Det gäller framför allt personer vars arbetssituation i realiteten inte erbjuder de positiva konsekvenser som handläggarens argument förespeglar.

\section{4) Moraliska argument}

De moraliska argumenten är kopplade till plikten eller skyldigheten att arbeta. De är mest förekommande när klienten uppfattas som ovillig att återgå till arbete eller visar tveksamhet inför de åtgärder som föreslås av handläggaren. Handläggarna ger ofta följande uttalanden: walla har skyldighet att försörja sig själva», ibland med tillägget "i Sverige", "man kan arbeta fast man har smärta" eller "många som har handikapp av olika slag vill inget hellre än arbetar. I ett möte berättar klienten - en invandrarkvinna som talar dålig svenska - att hon har ständig värk som gör att hon har svårt att sova, inte kan utföra något arbete $\mathrm{i}$ hemmet och har koncentrationssvårigheter. Hon säger att hon inte vill något hellre än att bli frisk och att hon då kan börja arbeta. Handläggaren svarar med att säga att klienten nog får ställa in sig på att hon inte kommer att bli helt fri från sin smärta, men att hon därmed inte betraktas som arbetsoförmögen enligt försäkringskassans sätt att se på saken. Handläggaren nämner också att klienten bör prioritera utredning om arbetsträning, framför andra aktiviteter, t.ex. semester med familjen, som klienten nämner att hon drömmer om. Som observatör kan jag förnimma en starkt moraliserande underton $i$ handläggarens i ord och röstläge. Handläggarens ansiktsuttryck och gester förstärker min upplevelse.

Några klienters påpekanden om att de inte vill "leva på bidrag" kan ses som försvar mot den misstänksamhet mot bidragsfusk som finns i samhället, bland arbetskamrater och hos handläggaren. Han eller hon vill inte bli betraktad som en ımoraliskı bidragstagare.

\section{5) Ideologiska argument}

De ideologiska argumenten handlar om rätten att arbeta. De används för att förstärka och stödja klienter som uppfattas sträva efter att återgå till arbete. När det gäller rätten till arbete handlar det om åtgärdsinriktade handlingar som att ge praktiskt stöd genom att anlita olika rehabiliteringsaktörer för att utreda klientens möjlighet på arbetsmarknaden, förmedla kontakt eller följa med till t.ex. arbetsförmedlingen. 
När moraliskt och ideologiskt färgade argument används tycks handläggaren utgå ifrån att klienten ımåster dela eller faktiskt delar handläggarens egna värderingar kring arbete. Handläggarna väljer argument som bygger på värderingar som anses vara gemensamma för alla i samhället. Det kan tolkas som att handläggaren framför sina argument ur ett etnocentriskt perspektiv (jfr Soydan 1995).

\section{6) Inherenta argument}

I en del observationer återfinns argument som utgår från antaganden om en inneboende nytta med arbete i sig, s.k. inherenta argument. Arbete i sig antas vara en aktivitet med terapeutisk verkan. För det första anses arbetet skingra tankar på sjukdom och smärta, samt motverka depression och alkohol- och annat drogberoende. "Arbete kommer att göra dig gott» är ett argument som används i flera av observationerna. För det andra kan arbetet förhindra individen från att falla in i ett sasocialt liv genom att det strukturerar tiden. Att ha arbetstider att passa skiljer av arbete och fritid och hjälper till att hålla en normal dygnsrytm. Dessa argument används när klienten inte kan återgå till sitt vanliga arbete, utan hänvisas ett lättare arbete, kanske med lägre status än det ordinarie arbetet.

De inherenta argumenten kan ibland vara svåra att särskilja från de sociala. Underförstått i mer generella positiva utsagor om arbetet finns troligen också antaganden om att arbete leder till sociala relationer och status.

Det är inte bara handläggaren, utan också några klienter själva som tar upp dessa argument. Det gäller klienter som uttrycker stark motivation för arbete generellt eller behov att komma igång efter bortavaro från arbetsmarknaden.

\section{Konfrontation mellan teori och empiri - en sammanfattning}

Genom att konfrontera de teoretiskt härledda incitamenten för arbete med de i empirin grundade argumenten som handläggarna använder för att implementera arbetslinjen erhålls figur 2 (se nästa sida). I figuren illustreras även hur de bakomliggande mekanismerna kan kopplas till argumenten.

Vid en bedömning av enskilda möten finner jag att handläggaren försöker förena olika typer av argument för att implementera arbetslinjen. De byråkratiska argumenten, som bygger på att individen måste följa regelsystemet och handläggningsrutinerna kombineras med argument som bygger på antaganden om individuella drivkrafter för arbete och konsekvenser av arbete. Vilka drivkraftsargument som kommer att dominera under mötet blir beroende av klientens responser och kan skifta under mötes gång.

\section{Skillnader i möten med invandrare och svenskar}

I detta avsnitt kommer speciell uppmärksamhet att riktas mot möten med invandrarklienter. Den fråga som ställs är: Vilka effekter har handläggarnas argument för arbetslinjen i mötet med invandrarklienter? Jag kommer att försöka besvara frågan genom att analysera och diskutera skritiska händelserı, dvs. situationer under klientmötet som ur ett observatörsperspektiv verkar komplicerande och problematiska just på grund av

Tola. B Jonsson - Implementeringen av arbetslinjen... 


\begin{tabular}{|c|c|c|}
\hline \multicolumn{3}{|l|}{ Figur 2} \\
\hline $\begin{array}{l}\text { Bakomliggande } \\
\text { mekanismer }\end{array}$ & Incitament för arbete & Handläggarnas argument för arbetslinjen \\
\hline Byråkratisk auktoritet & $\begin{array}{l}\text { Byråkratisk maktutövning: } \\
\text { Tvingande incitament } \\
\text { (regelsystem och hand- } \\
\text { läggningsrutiner) }\end{array}$ & $\begin{array}{l}\text { Byråkratiska argument: } \\
\text { Informations- resp. övertygelsestrategin } \\
\text { används }\end{array}$ \\
\hline Arbetets värde & $\begin{array}{l}\text { Arbetets primära } \\
\text { konsekvenser: } \\
\text { Materiella incitament } \\
\text { (t.ex. konsumtion) } \\
\text { Arbetets sekundära } \\
\text { konsekvenser: } \\
\text { a) Sociala incitament (t.ex. } \\
\text { involvering, identifikation) } \\
\text { b) Moraliska incitament } \\
\text { c) Ideologiska incitament } \\
\text { d) Inherenta incitament } \\
\text { (spänningsreducerande) }\end{array}$ & $\begin{array}{l}\text { Sociala argument: } \\
\text { Relationer och status betonas } \\
\text { Moraliska argument } \\
\text { Kopplas till skyldigheten att arbeta } \\
\text { Ideologiska argument: } \\
\text { Kopplas till rätten att arbeta } \\
\text { Inherenta argument: } \\
\text { Arbetet anses avleda från asocial } \\
\text { aktivitet och ha terapeutiskt verkan }\end{array}$ \\
\hline
\end{tabular}

klientens invandrarskap. Jag kommer också att lyfta fram de skillnader som jag har observerat i möten med invandrarklienter respektive svenska klienter.

I observationerna återfinns fyra kategorier av 'kritiska händelserı, nämligen 1) språkliga och kulturella uttryckssätt, 2) oenighet om roller, 3) tecken på arbetsovilja, och 4) oenighet om livsprioriteringar.

\section{Språkliga och kulturella uttryckssätt}

För mig som observatör framstår klientens språkliga tillkortakommanden som tydliga reella hinder i kommunikationen mellan parterna. Samtalen som förs med en klient som talar dålig svenska - även när samtal förs genom tolk - innehåller nästan alltid missförstånd. Många av missförstånden ut- reds inte. Ibland beror det på att parterna inte uppfattar missförstånden. Ibland försöker en eller båda parterna förtydliga sina ståndpunkter. Resultatet blir ofta att parterna fortsätter att prata förbi varandra eller ger upp efter några misslyckade försök.

Klienter som har svårigheter att nyansera sig språkligt är många gånger fåordiga i sina svar, ställer få frågor, lämnar inte ut sina tankar osv. Handläggarna uppfattar dessa klienter som svåra att arbeta med. De visar inte tydligt att de förstått vad man vill uppnå med rehabiliteringen.

Däremot kan deras beskrivningar av de fysiska besvären och arbetsoförmågan vara uttrycksfulla. Gester, tårar och suckar säger ibland mer än ord. Det här skapar en speciell svårighet för handläggarna. Att bedöma sjukdom hör inte till handläggarnas uppgif- 
ter, utan läkarens. Samtal kring sjukdom nedtonas därför av handläggarna. Det görs oftast genom att klienterna avbryts med hänvisningen till »du får tala med din doktor om dina besväru. Därefter leds samtalet in på ämnet arbetsförmåga eller olika åtgärder. I möten där klienten betonar sin sjukdom uppstår ofta en viss irritation hos handläggaren om klienten dröjer sig kvar vid eller återkommer till ämnet. Ett bestående intryck som jag har efter att ha deltagit i flera sådana situationer blir att man i kontakterna med försäkringskassan helst inte ska tala om sina besvär, speciellt om de inte har stöd i läkarintyg.

Även samtal med svensktalande innehåller missuppfattningar. Skillnaden ligger i att de för det mesta uppfattas av någon av parterna och reds ut under samtalets gång. En annan skillnad som kan iakttas är att svensktalande ställer fler frågor om hur systemet fungerar och hur man kan tolka regler och rutiner i relation till det egna fallet. Detta förhållningssätt ger större möjligheter för parterna att förstå varandra. Svensktalande visar också större känslighet för vilka ämnen som är lämpliga att driva eller tona ner. Ur observatörsperspektivet verkar kommunikationshindren inte att ligga på ett renodlat språkligt plan. Kulturella sätt att uttrycka sig och förhålla sig till myndighetspersoner påverkar relationen. Sättet att använda hälsningsfraser, artikulera frågor, visa artighet och betona vissa ämnen kan också fungera som kommunikationshinder. Inom kommunikationsforskningen har detta uppmärksammats. Som exempel kan nämnas Gumperz (1992) studie av interkulturella intervjusituationer. Han fann att man i möten med personer som inte uttrycker sig språkligt eller kulturellt korrekt tendera att falla in i ett kulturbundet beteende. Både språkliga och kulturella uttryckssätt bidrar till svårigheter för parterna att nå varandra.

\section{Oenighet om roller}

I riktlinjerna för sjukförsäkringssystemet definieras olika aktörers roller och ansvarsområden. Försäkringskassan har en samordningsroll som innebär att utreda behov och initiera insatser. En förutsättning för att försäkringskassans handläggare skall kunna utföra sitt arbete som handläggare är att de övriga aktörerna uppfyller sina roller. Arbetsgivarna skall stötta den anställde genom att bl.a. göra en rehabiliteringsplan. För läkarna gäller att de skall svara för medicinsk behandling och skriva intyg. Klienten förväntas lämna riktiga uppgifter och aktivt medverka i rehabiliteringen.

Rehabiliteringshandläggare och läkare har definierade roller i sin yrkesutövning i relationen till klienten eller patienten. De är sjukförsäkringssystemets sprofessionella aktörer. Även arbetsgivare har lagstadgade åtaganden vad gäller rehabilitering av långtidssjuka. Den långtidssjuke som kommer i kontakt med sjukförsäkringen kan däremot ses som organisationens noviser. Därför behöver de information om hur systemet fungerar och vad som förväntas av dem.

I relationen till klienten använder, som tidigare nämnts, handläggaren olika strategier för att förmedla reglerna till klienten. Ett av syftena är att uppnå ett samarbete som bygger på att klienten förstår och följer spelreglerna, dvs. ısamspelsmodellenı. Två klientresponser som rubbar isamspelsmodellen och som ofta förknippas med invandrarklienter, då i första hand de som talar dålig

Tola. B Jonsson - Implementeringen av arbetslinjen... 
svenska, är den passiva respektive den aggressiva. De spassivar invandrarklienterna lyssnar artigt och tyst på handläggarens information och förslag om åtgärder. När de sedan tillfrågas om det är något de undrar över blir svaret nekande. I det mest tydliga exemplet bland de observerade mötena svarade klienten när hon tillfrågades om sina synpunkter: „Jag gör som du säger, du bestämmer». En handläggare som möter detta svar blir förvånad och tystnar. Min tolkning är att handläggarna tar för givet att klienterna faktiskt ska visa intresse för vad som kommer att hända dem. När en klient svarar sfelı vet handläggarna inte riktigt hur de ska agera. Ibland fortsätter handläggaren efter en stund med att, trots klientens visade ointresse, beskriva vad klienten kan förvänta sig. Ibland tittar hon bara på klienten, hoppar över detaljerna och ger praktiska instruktioner om när och var klienten skall infinna sig. Flera handläggare uppger vid våra samtal att passiva förhållningssätt inte är undantag, utan en vanlig respons framför allt från invandrarkvinnor från t.ex. medelhavsländerna.

De aggressiva förhållningssättet innebär att klienten inte accepterar det handläggaren säger. Det kan gälla förslag om åtgärder eller tolkningar av olika utlătanden eller intyg. Klienten har en uppfattning om hur hans eller hennes situation ser ut och hur den skall lösas. De ifrågasätter handläggarens sätt att handlägga ärendet. Handläggarens försök att följa handläggningsrutinerna leder till att klienten ifrågasätter om han eller hon får en rättvis behandling. Ofta görs jämförelser med bekanta som fått en annan bedömning. Klienten riktar sin aggression mot handläggaren och kräver att få byta handläggare eller prata med chefen. De kan även hota med att begära hjälp från advokat eller överklaga beslut. Enligt handläggarna förekommer ganska ofta att hoten och kraven omsätts i handling.

Det är svårt att säga hur vanlig denna reaktion är. I observationsmaterialet finns ett par exempel på aggressiva klienter med invandrarbakgrund. En av dem är en utomeuropeisk man som anser att han med stöd av läkarutlåtandet är sjuk och inte kan arbeta. Handläggarens krav på att gängse rutiner med sikte på arbete skall följas uppfattar han som ogint och felaktigt handlande från handläggarens sida. I detta fall använder handläggaren inledningsvis informationsstrategin, för att förklara de olika parternas ansvarsfördelning. Hon upprepar samma budskap flera gånger. Klienten tar dock inte till sig handläggarens information. Han nämner att han vill ha advokathjälp för att få sin rätt. När handläggaren förstår att hennes budskap inte går fram växlar hon till ıövertygelsestrateginı och hotar med indragning av sjukpenning om klienten inte är villig att följa handläggningsrutinerna. Hon ser sig alltså tvingad att använda sin byråkratiska maktposition för att driva igenom att rutinerna följs. Mötet slutar med att klienten ger efter för trycket och säger att han skall ställa upp på de krav som handläggaren ställer på honom.

Som observatör kan jag känna hur spänningen trappas upp under mötet. Trots att handläggaren agerar mycket lugnt och tålmodigt har det ingen lugnande inverkan på klienten. Hennes stillsamma upprepningar verkar tvärtom provocerande på klienten. Efter ett tag känner klienten att han i den uppkomna situationen framstår som enfal- 
dig. Han säger: „Jag är inte dum. Jag förstår vad du säger«. När handläggaren sedan byter strategi och sätter hårt mot hårt ändrar även han strategi och 'ger upp،. En del av den uppskruvade stämningen släpper därmed, men för parterna finns säker många upprörda känslor kvar långt efter att de har skilts åt.

Ungefär samma händelseförlopp skulle kunna utspela sig om klienten varit svensk och parterna råkat i konflikt om roller och ansvarsfördelning. Även när klienten är svensk eller invandrare som talar bra svenska uppfattas ärendet som besvärligt när en konflikt uppstår. Skillnaden ligger i att handläggaren i möten med svenskar utgår från att klienten förstår hur systemet fungerar. I mötet med en klient som uppfattas ha språkliga och kulturella handikapp däremot är handläggaren inte säker på att klienten riktigt har förstått varför handläggaren ställer vissa krav. I dessa fall bygger klientens medgörlighet enbart på att han eller hon tillerkänner den byråkratiska makten legitimitet och att tvång därmed verkar som incitament. Det stämmer inte med den förgivet tagna ısamspelsmodellensı innebörd.

\section{Tecken på arbetsovilja}

Arbetslinjen bygger på antaganden om arbetets betydelse och funktion för den enskilde och kollektivet. Föreställningen om att alla skall försörja sig själva i det svenska samhället, och att detta är en jämlikhets- och jämställdhetsfråga implicerar moraliska aspekter. Att skilja de värdiga klienterna från de ovärdiga tillhör den kontrollerande sidan av handläggarrollen.

I den kontrollerande rollen som välfärdsbyråkrat skall handläggarna bedöma om kli- enten kan, vill eller får arbeta. Midré (1990) menar att en sådan bedömning sker utefter tre dimensioner. Moraldimensionen handlar om att klienten visar vilja att bli frisk och försörja sig själv. Utifrån resursdimensionen avgörs om klienten kan, dvs. har resurser att försörja sig själv. Marknadsdimensionen berör klientens möjligheter att få ett arbete.

Inom sjukförsäkringssystemet läggs marknadsdimensionen i första hand på arbetsgivare och arbetsförmedling. Bedömning av sjukdom och arbetsförmåga kan föras till resursdimensionen. Det är läkarna som skriver intyg om sjukdom och arbetsförmåga. Rehabiliteringshandläggarna gör sedan utifrån läkarintyg, klientens utsagor, arbetsträning $\mathrm{mm}$ en helhetsbedömning av arbetsförmågan.

I observationerna framkommer också att handläggarna gör bedömningar efter moraldimensionen. Hur detta görs är svårt att få grepp om, men tydligt är att handläggarens misstänksamhet om att klienten inte är arbetsvillig ibland väcks. Den kontrollerande uppgiften i rollen i kombination med den starka betoningen av arbetslinjen innebär att handläggarna har en vakenhet för tecken på arbetsovilja under mötet och rehabiliteringsprocessen som helhet. Hur väcks då handläggarnas misstänksamhet om arbetsovillighet? En omständighet som väcker misstanke är fall med s.k. diffusa besvär. Det kan vara diagnoser som är svårtolkade som ryggbesvär, värk, ledbesvär, magsjukdomar, m.m. En annan omständighet är när olika aktörers omdömen inte stämmer överens. Kanske stämmer inte läkarutlåtandet eller arbetsträningsresultatet med klientens egna upplevelser av sin sjukdom och sina besvär. Det kan även vara så att hand-

Tola. B Jonsson - Implementeringen av arbetslinjen... 
läggarna gör en annan bedömning än läkarna, eller bedömer läkarutlåtandet annorlunda än klienten som i exemplet ovan. Diskrepanser i sig verkar alltså mobilisera misstänksamhet.

Två grupper av klienter som handläggarna uppfattar som arbetsovilliga kan urskiljas. I den ena gruppen hamnar de som direkt i ord uttrycker att de inte anser sig kunna arbeta. Det kan röra sig om att klienten när handläggaren föreslår rehabiliteringsåtgärder säger: "Först vill bli jag bli frisk». Sådana uttryck anses av handläggarna, som omoraliska, då de anser att klienten bör kunna tänka bortom sjukdomen, dvs. planera för en framtid med arbetsförmåga. Det är en respons som av handläggarna uppfattas som ett invandrarargument, dvs. vara kulturellt betingat. I den andra gruppen placeras de som på ett mera subtilt sätt tycks planera för förtidspension. De kan vara så att klienten kanske säger ja till en åtgärd, t.ex. arbetsförmågetest och arbetsträning, som han eller hon sedan inte fullföljer. Det omoraliska ligger då i att de inte anstränger sig för att bli friska. I båda fallen är handläggarnas förklaringar till beteendet att det beror på t.ex. ödestro, lathet, brist på rationalitet, brist på eget ansvar, m.m.

Finns det några förklaringar till att moraldimensionen får starkare framtoning $i$ möten med vissa invandrarklienter? I jämförelse mellan invandrare som uppfattas som arbetsvilliga respektive arbetsovilliga finns en skillnad i klientens framtoning. De som uppfattas som arbetsvilliga använder referenser i det svenska samhället för att förklara hur de ser på arbete. De poängterar att de vill göra rätt för sig, försörja familjen, inte vara som andra invandrare osv. Det är argu- ment som faller i god jord hos handläggarna. Dessa klienter framstår alltså i de observerade samtalen som mera lyhörda när det gäller att reagera på de krav som handläggarna ställer, och svarar kulturellt sriktigtı, vilket uppfattas som om de tar ansvar för sitt eget liv, sin egen och familjens försörjning, försöker vara nyttiga samhällsmedborgare, osv. Några invandrarklienter påpekar särskilt att de inte vill "leva på bidrag». Dessa klienter säger uttryckligen att de vill arbeta och göra rätt för sig, och att de inte vill att handläggaren, arbetskamraterna eller svenskar i allmänhet skall tro att de är arbetsovilliga. En kvinna säger: „Mina arbetskamrater tror att jag inte vill arbeta. De säger att jag bara vill ligga hemma och se på TV. Men det är inte sant. Jag vill verkligen arbeta, men jag orkar inte för mina besvär«. Ett par klienter anger också de känner att misstänksamhet om att de är arbetsovilliga riktas mot dem just för att de är invandrare. En invandrarman säger: „Jag vill jobba. Jag är inte som andra invandrare."

\section{Oenighet om livsprioriteringar}

I handläggarnas argument för arbetslinjen finns underförstått att arbetet bör prioriteras framför andra alternativ som klienten kan tänkas sätta före, t.ex. familjeliv och fritid. För dem som blir friska och återfår hel arbetsförmåga innebär det oftast att man återgår till sitt vanliga liv. För dem som inte blir helt återställda efter en sjukdom och får nedsatt arbetsförmåga väcks ofta frågor om hur de reducerade krafterna och energin skall fördelas mellan arbete, familj och vila/ rekreation. Klientens arbetsmotivationen kan antas bli beroende av hur han eller hon bedömer sin situation. 
I vissa möten kan tydligt iakttas att handläggarnas och klientens bedömningar görs utifrån olika perspektiv. Handläggarnas argument utgår från arbetslinjen, medan klienten gör sin bedömning utifrån ett helhetsperspektiv på det egna livet. Det gäller inte minst när de sociala argumenten som används i möten med invandrarkvinnor skärskådas. I dessa fall handlar det ofta om klienter som har dålig kontakt med arbetskamrater, t.ex. på grund av språkhinder eller arbetets organisering. Klienterna kan också ha bättre fora för att utveckla relationer, t.ex. stort umgänge med släkt och vänner. Även när det gäller statusargumentet finns i observationerna tecken på att detta argument inte heller alltid stämmer med klientens livssituation. I vissa fall framkommer att det arbete som man försöker rehabilitera till, av klienten inte uppfattas ha tillräckligt hög status. Handläggarnas argument verkar grunda sig på mera generella antaganden om statusen $i$ att överhuvudtaget ha ett arbete, än på den enskilda klientens specifika situation.

Klienternas reaktion på sociala argument kan alltså antas variera beroende på de egna erfarenheterna. Likaså är fallet vad gäller de inherenta argumenten. För många av de långtidssjuka i observationsstudien gäller att de kan sätta sina sjukdomsbesvär i samband med sitt arbete. Även om klienten har en välvillig inställning till arbete i allmänhet och dess positiva effekter så är de inte säkert att han eller hon vill àter till ett arbete som bidragit till sjukdom.

I några möten framstår dessa skillnader som gäller livsprioriteringar som viktiga och problematiska. Det kan vara svårt att känna entusiasm för att återgå till ett arbete som är tungt och monotont och förorsakade sjukdom. För flera av invandrarklienterna i observationsmaterialet är detta en realitet; det gäller inte minst kvinnorna. Lönearbetets sociala och inneboende vinster kan naturligtvis med rätt ifrågasättas av dessa klienter.

Klienterna verkar också ha klara uppfattningar om sina egna möjligheter att få andra anpassade arbeten hos sin arbetsgivare och på arbetsmarknaden i stort. Vilka möjligheter har en lågutbildad på arbetsmarknaden idag? Vad händer om man dessutom är invandrare och kanske kvinna? Vilka chanser har den som inte talar svenska? Lägger man till ett arbetshandikapp gör det inte saken lättare. Alla dessa faktorer vägs in i klientens bedömning av situationen och slår igenom i mötet med handläggaren. I de fall skillnader kan observeras mellan parterna tycks de ha sin grund i att handläggarna utgår från mer idealistiska bilder av hur verkligheten ser ut än klienten som utgår från egen erfarenhet.

Man kan anta att verkningarna av sociala och inherenta argument får liten eller kanske till och med negativ verkan när de från klientens perspektiv inte stämmer med dennes upplevda situation. I några av observationerna framkommer särskilt tydligt hur pressade klienter kan bli när handläggarna lägger ner stor energi på att genomdriva arbetslinjen. Flera av klienterna berättar att deras fritid består av att vila så att de skall kunna arbeta och hur familjemedlemmar i omsorg om klienten får ställa upp med markservice och personlig omvårdnad. Några klienter tycks också anse aut det är ett naturligt sätt att leva. Andra däremot visar direkt eller indirekt att de gör andra priorite-

Tola. B Jonsson - Implementeringen av arbetslinjen... 
ringar. Det gäller t.ex. några kvinnor som antingen själva säger att de prioriterar familjen eller av handläggarna misstänks göra det. De möts av dubbla budskap från handläggarnas och samhällets sida. Hemarbetet som tidigare inte räknats som arbete, dvs. inte varit sjukpenninggrundande, blir plötsligt synligt och ett hinder för att få ersättning från sjukförsäkringen. Den som prioriterar att orka med sysslor inom hemmets sfär, speciellt om det går utöver det som anses inormaltı, t.ex. ta hand om en stor familj eller ett handikappat barn, hotas ibland med indragning av sjukpenning eftersom det visar att klienten har arbetsförmåga vilket $i$ sin tur utdefinierar klienten ur systemet. Frågan om vad som räknas som arbete och var gränsen för arbetsoförmåga går aktualiseras i dessa fall.

Klienter kan protestera mot sociala och inherenta argument, antingen öppet eller mera dolt. Att protestera öppet kan innebära att klienten försöker förklara att handläggarens anförda argument inte gäller för den egna situationen. Klienten anstränger sig för att få handläggaren att förstå den unika livssituation som han eller hon befinner sig i just nu och hur han eller hon tänker sig framtiden. I de fall klientens beskrivning av sin situation uppfattas som trovärdig och anspråken som rimliga skapar de sällan några problem för systemet. Uppfattas skälen som orimliga avstängs klienten från ersättning. När det gäller trovärdigheten finns en viss skillnad mellan klienter som uttrycker sig språkligt och kulturellt korrekt och de som brister i något av dessa avseenden. I de fall språkliga och kulturella hinder finns är det svårt att bli trovärdig och ställa rimliga anspråk.
Att protestera dolt kan innebära att inte delge handläggarna sina tankar och planer för framtiden. Detta förhållningssätt uppger handläggarna vara svårt att handskas med. Klienten är medgörlig genom att delta i föreslagna åtgärder, ofta utan förväntat resultat. Det rör sig ofta om de ıpassivar klienterna som nämndes tidigare.

\section{Slutsats}

Arbetslinjen är den styrande principen inom sjukförsäkringen. I det faktiska mötet mellan handläggare och långtidssjukskrivna skall denna princip omsättas i praktisk handling. Handläggarna vid det studerade försäkringskassekontoret uppger att möten med invandrarklienter är särskilt problematiska. I denna artikel har jag anfört att begreppen byråkratisk auktoritet och arbetets värde kan ses som bakomliggande mekanismer i mötet mellan handläggare och klient. De blir betydelsefulla i det meningssammanhang som sjukförsäkringen utgör. De sargumentı som handläggarna använder i klientmötet, liksom de ıkritiska händelserı som uppstår i mötet med vissa invandrarklienter kan knytas till dessa begrepp eller mekanismer.

I mötet med klienter använder alltså handläggarna olika sarguments för att implementera arbetslinjen. Ofta kombinerar de dessa argument. Vilka argument som dominerar i det enskilda mötet beror på den samlade tolkning som handläggaren gör av situationen och kommer att växla i samspelet med den enskilde klienten. De byråkratiska argumentens, dvs. hänvisningar till regelsystem och rutiner, närvaro är påtaglig. När det gäller de argument som rör arbetes 
värde noteras att försörjningsargument förekommer relativt sällan. Meningssammanhanget visar att de när de nämns ofta har moraliska eller ideologiska implikationer. De sociala och inherenta argumenten används för att stödja klienten i dennas arbetssträvanden respektive visa omsorg, medan de moraliska och ideologiska argumenenten används dels för att ruppfostrar och dels för att stötta klienten. De fyra sistnämnda kategorierna av argument används ofta av handläggarna.

Fyra kategorier av ıkritiska händelserı som kan kopplas samman med klientens invandrarskap har identifierats. En granskning av kritiska händelserı ger vid handen att språkliga och kulturella uttryckssätt och oenighet om roller i första hand vållar problem kring frågor som rör den byråkratiska dimensionen. Främst då genom att den ssamspelsmodellı som enligt riktlinjerna förväntas gälla vid interaktion mellan handläggare och klient inte fungerar. Problemet kan då i huvudsak lokaliseras till att klienten inte förstår och/eller accepterar systemet. Men också för att det finns språkliga och kulturella hinder i kommunikationen. Det får till följd att klienten inte kan inordnas i systemet utan att byråkraten tydligt använder sin maktposition på ett sätt som kan tyckas hårdfört.

När det gäller kritiska händelserı som kategoriseras som tecken på arbetsovilja och oenighet om livsprioriteringar kan problemen förläggas till arbetets dimension. Handläggarens roll att som organisationens representant implementera arbetslinjen medför att bakomliggande föreställningar om arbetet och dess konsekvenser blir styrande för handläggarens sätt att agera.
Handläggarens starka organisationslojalitet, etnocentrism och bristande insyn i klientens livssituation bidrar till ett organisationsspecifikt sätt att förhålla sig i mötet (jfr Soydan 1995). Olika tolkningar av arbetsmoral och arbetets betydelse i klientens livssituation leder till konflikter.

En allmän slutsats som kan dras utifrån observationsstudien är att invandrarskap under vissa förutsättningar framstår som en komplicerande faktor vid implementeringen av arbetslinjen. De svårigheter som handläggarna stöter på i mötet med dessa klienter leder till störningar i deras självklara förväntningar om hur samspelet skall tillgå och rubbar därmed gängse byråkratiska handlingsrutiner. Skillnad i synsätt på arbetets funktion och betydelse leder även det till att konfliktfyllda situationer uppstår. En hypotes som växer fram ur detta är att ju fler invandrare desto fler komplicerade och frustrerande möten får handläggarna att hantera. Och ju fler komplicerade invandrarärendenı, desto mer problematiska upplevs dessa ärenden generellt. Det skulle kunna innebära att invandrare uppfattas som mer problematiska av handläggare som arbetar i invandrartäta områden än i områden där invandrarklienterna utgör ett fåtal.

Artikeln är skriven inom projektet „Långtidssjukskrivningar och förtidspensioneringar bland invandrare « som leds av docent Haluk Soydan.

Studien finansieras av Socialvetenskapliga forskningsrådet. Jag vill rikta ett särskilt varmt tack till docent Haluk Soydan som läst och kommenterat mitt manus.

Tola. B Jonsson - Implementeringen av arbetslinjen... 


\section{Referenser}

Friberg, M (1975). „Är lönen det enda som sporrar oss att arbeta? Del I." Sociologisk Forskning, $\mathrm{Vol} 12 \mathrm{Nr} 4$.

Friberg, M (1976). „Är lönen.. Del II.« Sociologisk Forskning, Vol $13 \mathrm{Nrl}$.

Gumperz, JJ (1992). »Interviewing in Intercultural Situationsu. I: Drew, P, Heritage, J, red.

Talk at Work. Interactions in Institutional Settings. Cambridge: Cambridge University Press.

Jahoda, M (1981). „Work, Employment, and Unemployment. Values, Theories, and Approaches in Social Research". American Psychologist, Vol 36 No 2:184-191.

Johansson, R. (1992). Vid byråkratins gränser. Om handlingsfrihetens begränsningar i klientrelaterat arbete. Lund: Arkiv Avhandlingsserie. Jonsson, TB (1996). Institutionalized strategies in face-to-face encounters. Rehabilitation workers and clients in a social insurance office.
Scandinavian Journal of Social Welfare, $\mathrm{nr} 3$.

Karlsson, JCh, Jacobsen, L, Blomgren, E (1991).

Realism inom humanvetenskapen - och ett planeringsproblem. FOA rapport C5000875.3. Sundbyberg: Försvarets forskningsanstalt.

Lipsky, M (1980). Street-Level Bureaucracy. Dilemmas of the Individual in Public Services. New York: Russel Sage Foundation.

Midré, G(1990). Bot, bedring eller brød. Oslo: Universitetsförlaget.

Miles, MB, Huberman, AM(1994). Qualitative Data Analysis. An Expanded Sourcebook. Second Edition. Thousand Oaks/London/New Delhi: Saga Publication

Prop. 1990/91:141.

Prottas, JM (1979). People-Processing. The StreetLevel Bureaucrat in Public Bureaucracies. Lexington: Lexington Books.

Sayer, A (1984). Method in Social Science. A Realist Approach. London: Hutchinson.

\section{Summary}

\section{The implementation of the working-track principle in social insurance Consequences for immigrant clients}

The aim of this article is to identify and describe how the 'working-track' principle is implemented in encounters between the officials at the social insurance office and their clients. Special attention is given to immigrant clients.

The 'working-track' principle is the guiding principle within the social insurance system in Sweden. In this article I have identified rarguments that officials working with vocational rehabilitation use when implementing the 'working-track' principle in encounters with clients. The officials often perceive immigrant clients as problematic to deal with. For that reason I have focused on 'critical incidents' connected to immigrant factors during the encounters. I also indicate, through a process of abstraction, that the concepts of bureaucratic authority and value of work may operate as causal mechanisms in encounters between the officials and their clients.

The data consist of 24 observations of encounters between the officials and their clients, and of interviews with the officials about their experiences of these very encounters.

The analysis shows that the officials use 
arguments that fall along two different dimensions: the bureaucratic dimension and the work dimension. The bureaucratic dimension concerns the assumption that the power of the official as a representative of the organization is legitimate. The work dimension is about assumed motives to work. The identified arguments can be divided into six categories: 1) bureaucratic arguments; 2) earning-a-living arguments; 3) social arguments; 4) moral arguments; 5) ideological arguments; and finally 5) inherent arguments. In a given encounter the official combines different arguments. During the ongoing interaction between the parties the arguments vary because of the clients' responses.

Four different categories of 'critical incidentsi connected to immigrant factors were found. An examination of the 'critical inci- dents' shows that linguistic and cultural performances and different opinions of duties and responsibilities cause problems connected to the bureaucratic dimension, and signs of unwillingness to work and disagreements over life priorities cause problems in connection with the work dimension.

In conclusion, the study shows that under special circumstances immigrant factors will stand out as complicating factors when the officials try to implement the 'working-track principle. This is especially evident when clients cannot express themselves as trustworthy due to linguistic or cultural performances. The difficulties that the officials face lead to disturbances in the bureaucratic routines, which in their turn generate frustration. Immigrants become, in general terms, a problematic group to deal with. 